\title{
The Preservation of Pau Brazil in the Late XVIII Century in an Economical Perspective
}

\author{
Edgar Teles \\ Social and Human Sciences of the New University, Portugal
}

Copyright $\subseteq 2019$ by authors, all rights reserved. Authors agree that this article remains permanently open access under the terms of the Creative Commons Attribution License 4.0 International License

\begin{abstract}
This paper's subject is the deforestation of Pau-Brazil in late XVIII century Brazil witch can be integrated in the academic inquiry into the question of the natural and cultural heritage. In this subject the author has written this paper not only in a statistic data, but in connection with the history of environmental ideas. The author has obtained some percentage values that allowed him to provide some realistic dimension to the lack of the woods in this area, and connecting the same data with the ecological and economical thought dimension. About the subject in the end of the XVIII century (1796 - 1798), there is a shortage of Pau-Brazil timber in Pernambuco, that takes an effort both of searching for new forests and a strong effort also of developing preservation measures in that period. The trade of Pau-Brazil in the late XVIII century could reach as profit the percentage values of (778, $71 \%$ ) in the European markets of the end of the XVIII Century. In this case, the author's argumentation concerns - in this historical context - how an economical interest paradox has triggered an interest about environmental protection to save an important accent. This involves at the beginning to identify the species of Pau-Brazil that were in use at the time in the same region to, in a second stage, integrate the same in the economic importance in Portuguese trade economy. The third step is to understand the correlation between economy and environment in the search of new forests and preservation of the already known ones. In this part, it is important to remember that early modern economies were natural commodity based and thus very dependent on the environment. That (should have) urged them to insure that they had a continuity on the access, and to ensure the existence of the same resources. This enters in Richard Groove's theories about environmental history in connecting them with economy. And also Wades' theories, that cross ecology with other sciences. Being a work in history, the main propose here is not to give a solution of mine, but rather to present the question in which the context were occurred and how and what solutions were found in the same period, and to what degree.
\end{abstract}

Keywords Pau-Brazil, Deforestation in XVIII Century, Economy and Ecology, Preservation of Pau Brazil

\section{Introduction}

In the late XVIII century, there were reports sent to the Portuguese crown about the reduction, and nearly total extinction, of Pau-Brazil woods in Pernambuco. The same danger of extinction occurred in a period that Portuguese economy was passing by an unquestionable prosperity, based on the re-exportation of goods from Brazil. Most of them were from agriculture and natural commodities, but neither all of them were; from the total of 125 products reexported from Brazil and $80 \%$ where form de sertão. One of those goods was Pau-Brazil, that growth in the sertão of the capitania de Pernambuco, and is timber was used in clothing manufactures, the red color extracted from its boiling was used to painting clothes, and naval constructions. In a general view the absence of any good could unbalance Portuguese re-exports to a deficient trade balance, which was against the notion of wealth of mercantilism (the dominant economical paradigm in Portugal). Under the practices of the same economical field, wealth was achieved by a favorable trade balance, which would reverse the logic of that payment that should be done to Portugal in gold. The loss of a good or its decrease in exports could seriously unbalance the trade making it unfavorable against Portugal. In a context were Portuguese trade was experiencing an increasing prosperity, the most of the goods available to reexportation made the same goal possible to be reached. In this context a natural good, with some weight in the economy could, with its disappearing, in a moment of economical wealth, trigger the necessity to proceed to its conservation. To study this devastation, of the treadable resource, and the measures taken to stop and reverse that process, it's required an approach it's required between economic and ecological history. The major purpose in 
the connection of those subjects is not to create a major theoretical interpretation, but to see what real measures were taken to conserve this good and what ecological principles where established, with all the limitation in the use of that concept. Nevertheless, to do so, it's required to understand the theoretical field of both currents to approach a point of contact. But prior to that, it is required to understand the XVIII century relation with the natural world. The concept of Nature was withering then the mere significance of natural world itself. It could mean also the natural propositions of society, faith, science and men. The XVIII century presents itself as a century of great transformations. Philosophically, the major debate upon nature was between two distinctive currents: the statique view of a nature that never changes, and the dynamical better known as transformism. When we use the concept of nature, we are using a diversity of meanings and usage in the early modern period. In a scientifically matter it is a period where geometry - as the basis to understand the natural world - was diminishing in influence, giving space to subjects as mathematics and physics as the core explanation how did the world work. Diderot (in an article in the Encyclopedia) divides the concept of nature in the following fields: Natural History composed by chemistry, experimental physics, in opposition to the nature of spirit and the nature of society. The same laws could be understood by experience, and observation. The concept itself, could mean and be used in: Natural History, nature of men, nature of the universe, and natural world. In this paper however, the concept will be used only in relation to the significance of the natural world.

The philosophical field of Natural History (founded by Plínio the elder) is older than the beginning of the overseas European expansion in the XVI century, but was reaching new reflection subjects in the XVIII century. As part of the same transformation, in the second half of the same century, a network was created based on botanic gardens and in the plant transfers where one the major objective was economic and agricultural potentialization and the profit they could provide in XVIII century trade [1]. This change it's also related to the development of natural history in the enlightenment period. One of the bases of natural history was the potential of natural goods, in connection with their usefulness to humankind, Influenced by the transformation in the core of scientific thinking. The discourse about nature was not a topic which emerged in the XX century as well her study. Influenced by natural history in which experimentalism was affirmed as the most important method to know nature, many scholars were sent aboard, to study nature of the world [2]. From the different parts of the world, they brought several species of plants to Europe to the botanical gardens as part of the study of nature. It is within that context, that the practices of preservation started to flourish because, besides this proposal, they gained a social part to create conscience about the deforestation and the need for preservation of the species. Preserving them, they could be exported, and be of interest to the wealth of a nation. As part of the new perspective according to Richard H. Groove, who gives examples of attempts of preservation in the Island of Saint Helena, some botanical gardens where created to preserve natural flora, In contrast to North America. In most to the temperate countries deforestation was seen as a damage that could affect the economy as well [1]. Botanic gardens, more than mere places for the delight of visitors, were a place where the use, properties, characterization of the plants and economical potentiality were evaluated. In the XVIII century there were three types of gardens in terms of their focus: pharmacies and scientific ones and economic ones [2]. On the other hand, one of the major goals was the study of all elements (biological, chemical, as well as planetary, i.e. astronomy) of all the elements that can be used by humanity or can affect human in habitation of earth. It's in this logic that the botanical gardens where created. The first type of gardens was dedicated to the study of the potentiality of the plants for medicinal use. The second type was dedicated to the study of the plants, with a scientific propose. The third type of botanical garden sponsored by state funding had as its main objective the economical potentialization of the plants. The botanical gardens, in their many definitions, albeit not as a main objective, did have a part on ecological preservation without intent to do so. The sheer act of exporting plants form different parts of the world to Europe or to the colonies around the world had as consequence the preservation of them, although not in their native habitat. The existence of economical Botanic Gardens implies that, despite that preservation of nature was based on the potentiality of natural goods, the creation of these same gardens follow the experimentalism practice. This meant that naturalists could study, understand, and define the properties of plants, and their better use. It is that transformation in science, and the better understanding, that brought the ideas of preservation to its main core or at least within the acknowledged context, that will be explored here for PauBrazil.

\subsection{Problem Staten}

In this context, where in the economic boom there was a non-agricultural product used in the re-exportation, what was the Portuguese crown's and local authority's solution to stop the deforestation and insure the endurance of the Pau-Brazil Woods?

\subsection{Questions Rose}

For the overall research question to be answered, there are several questions that should be answered. Why an economic matter did triggered an ecological concern, and 
who was behind this? In which points where in this case both of them in symbiosis? What where the appointed causes and how where they operative in the solving of the situation? How did economic concerns, and for what reasons, bring ecological questions? How can we define ecological history and measures in the XVIII century? What measures were taken by the Portuguese crown to address that situation?

\subsection{General Objectives}

Having stated the research problem and research questions, it is important to define the objectives of this work. The main objective is to determine how the scarce of an economic asset forced the crown to undertake some measures of preservation.

\section{Materials and Methods}

\subsection{Documents and Archives}

To undergo the present study I've made most of the research In A.H.U (a.k.a Arquivo Histórico Ultramarino), in the context of my M.A thesis research. There while consulting some historical sources about XVIII century Brazil, in the Avulso Documents of the Conselho Ultramarino, while reading the documents about the slave trade to Pernambuco, I've came across some sources about the shortage of Pau-Brazil. Those documents allow much work in a quantitative amount, but also a great deal of information about the deforestation and a situation of near extinction of the its near extinction, as well of the major preoccupations about the same question. The documents that provide more solid information about the phenomenon that danger that wood, and permit is work in an ecological perspective, are the correspondence between the Governador of Pernambuco, and the Conselho Ultramarino. That official correspondence between both organisms provides us non-quantitative sources that supplies facts so we can build the ecological perspective. In those official letters we find a great deal of concern about the possibility of extinction of the same wood, which lead them to establish causes and solutions about what could be the causes to the disappearance and what could be done towards its preservation.

Other documents, the Mapas de Carga (documents who show accurate quantitative information about the wood that was brought by ship from Pernambuco to Lisboa), had a great deal of quantitative data about how much of the wood in question was sent to Portugal. About the quantitative data it allowed me to do build graphics and tables using a great deal of different sources. Nevertheless it was not the only archive and sources, from where I collected and processed raw information.

Other archive in which I was able to access to a great deal of information was the I.N.E (Instituto Nacional de Estatistica), where I could complement the data of the quantities of Pau Brazil sent to Lisbon, with information of the re-exportation of the same product to Europe, allowing me to understand the its commercial weight in late XVIII century exportation's. That raw material granted me also, to have some complementary statistical data to cross information with that I've found in A.H.U.

Other archive that allowed me to collected raw quantitative data about this period was the ANTT/Torre do Tombo. There, after consulting the information about the Casa da Índia from the Alfândega de Lisboa, I collected other statistic information to establish the already mentioned comparative process.

This archival recoil allowed me to have the basis of this work. Beside the quantitative information, it allowed me to cross with a great deal of factors beyond the economical. Other questions are related with the writing of this paper. A great deal of information it's in Portuguese, so and due that some of it are offices, and some are name of regions I've chose not to translated them but put it in italic.

\subsection{Literature Revision Economical and Ecological History Coexistence and Connections}

Taken an account on the material used to formulate this paper, let's consider about the methodological basis of its elaboration. When the conceptual field about the composition of an article evolves two methods it's required to consider the scientifically revolution as theorized by Thomas Kuhn. According to the mentioned author when a paradigm can't provide response to the questions made, sciences entrails in a process of epistemological rupture; being the time where another paradigm emerges to provide new solutions. This methodological question can be connected with this paper because he links two academicals fields, economic and ecological history. This paper starts with an economical question, but the resolution doesn't pass by economy but instead by ecological solutions. There for, as a starting point, it should be defined the actual principles and problems that guides the debates in economic history; that matches with the notions of utilization by men, related to Natural History and Nature, that were part of the concept in the XVIII Century. That ambiguous significance makes it important to perspective the interaction of economy and environment and its historiography.

Most of economic historians wrote very few lines about nature, keeping their academical production over agriculture and industry. About the resources, when speaking of land, its referred arable land as well as the mines both considered sources of prosperity. In this context we should quote Cipolla that distinguishes between mono-productive resources, which are those that nature has no ability or difficulty to reproduce, and other 
nature resources [2]. The resources from the mines can be included in the category stated by the mentioned historian.

Economy however, can't be reduced to its mere disciple, being studied also in the History of Economical Thought. Even in that sub-theme, very little attention is given to nature. Mercantilism currents in relation to natural resources, with the exception of gold, did not have great expression in XVIII century economical thinkers and their writing [3]. Even the classical economists valued the products of nature only to the extent that they were free and soon did not present any expense, but did no great reflection about their importance. Even the questioning in relation to the soil, it's more related to an opposition to Malthus's theory and that of Adam Smith, where these would be niches of fertile land to be explored in the possibility of scarce productivity of land and agricultural land. This concept was still a differentiating factor as far as Malthus was concerned, being considered a nonsustainable good. However, the notion of this natural economy includes: soil, mines, and fisheries [4].The operability of this concept is, whoever, in turn, reduced since the trees - even those of the forest - were common throughout the $10^{\text {th }}$ century, were often planted.

In the modern age, in the European context, a deforestation process began in certain kingdoms, with the function of the collected wood supplementing energy and shipbuilding. On the issue of the forest, the theme has been more debated by ecological historians. This can be explained because of the methodology used by the economic history, and the sources that provide the data for their interpretation. Those series allow the creation of series, established by raw numerical data that allows establishing economical trends. In most cases, the goods extracted from the natural world, aren't accounted in statistic sources and when they are, it's not in an amount of data to create a long duration trend. This general lack of information makes it difficult to establish statistics that can provide both an economic and ecological interpretation.

The panorama of serial and statistical economic history is involved in the methodological dispute between serial history and econometric history. The debate between the two economic models is whether this historical current should be (Econometric History), with series established through mathematical models, or through a more ideological interpretation where Neo-liberalism serves more than a purely academic model. The same, beside a counterfactual history, presented not according to the parameters and data of the historical period itself, but rather as what might have been. The trap of counterfactual, it is held that by the absence of documents their logic can be manipulated and manipulative. With regard to micro economic standards, they fail to create efficient analytical models based on Neo-liberal models, since they do not allow us to perceive the specificity of the systems in question. These models, and the surrounding debate, have been more concerned with mathematical models. In this field, where the calculator and graphics synthesize, and create both models and instruments of analysis on the basis of interpretation, the understanding of the models as theoretical basis in the Neo-liberalism thinking [5]. However while serial history is based on mathematical models, it can only be applied to the ecological history if there are serial data from the collection of the forests, to have an accounting establishing either long, middle, or short duration cycles. In both currents the models are constructed based in sources with quantitative material that allows establishment of trends. Nevertheless serial history establishes the integration of this data in its historical context.

Seen some of the major issues of the economical history, it's time to establish the parameters of ecological history that can be connected with economic history/ history of economic thought. The environmental economy operates on the antipodes parameters of the neo-classical economy: consumption choice theory; perfect information and marginal distribution of production. This implicates, that the data worked quantitative, and serial data, must be interpreted beside the parameters and major subjects of the economy in correlation with ecology. In the case I'm studying the Paul-Brazil it enters between those fields of study. In spite of a apparently contradiction, some scholars begin working between those academical matters. The ecological economy, born of the intellectual boiling of ideas, challenges some of these assumptions and the economic system studying it as a subsystem of the ecosphere distributing energy, goods and raw materials in a social sphere [6]. It should be noted that, although most of the theories, whether economic or religious, of the period in question, do not have such a practical side, the same is not true of the natural sciences which were moved with a more practical approach [7]. In the context of the XVIII century those theories can act from the more pragmatic view of natural history whose main field of study was usefulness of the elements collected in nature for man's daily life [8]. This XVIII concept, in the ways it was developed in the period in study, allows a bridge to fully study both subjects as the base of the knowledge of nature.

Given account of the possible connections to the XVIII century, let us consider the themes were ecology and economy connects. The concept, as it begins to be academically operative in 1886 , refers to a system of interactive relation of nature with the whole which is called ecological economy [9]. In the 1970s aligned with the greatest interest for the American public as one of the most important subjects, it begun to focus on forestry goods [4]. One of the main objectives of History of Ecology it's the study and understanding in a time continues perspective, off the interaction of man and nature through the duration of Human history [10]. A more traditional historical approach is to analyze the 
transformation of the globe's ecology through themes like the separation of man from nature during the Neolithic revolution, imperialism and colonial expansion, exploration, agricultural change, the effects of the industrial technological revolution and urban expansion. More environmental topics include human impact through influences on forestry, fire, climate change, and sustainability and so on. According to Paul Warden, "the increasingly sophisticated history of colonization and migration can take on an environmental aspect, tracing the pathways of ideas and species around the globe and indeed is bringing about an increased use of such analogies and 'colonial' understandings of processes within European history [11]. In this line the main discourse, and study, is about the effects of the same socioeconomic current on the environment in the extraction of resources as a cause of their shortage.

The topics in question are related to the dilemmas themselves about the history of the environment in which they will integrate their narrative, if into a more traditional historical fields or into emerging historical narratives. In current methodology when crossing economic thought or economy with ecology, it was always perceived to be a paradox since it is believed that one is at the basis of the problems of the other [12]. However neither all theories take that premise as the only theory, as a practical example, when speaking of overseas history, we speak of plants and natural landscape where there humanity was one of the factors of transformation. This question and the degree of change of nature by the action of man and the role of nature in this dialectic, is one of the most frequent topics of approach establishing a dialectical relationship. In this field historiography leaves slowly the subject of the predominance of the role of man as agent of change, where the nature has a passive dimension, face to the active role of humanity on the environment that surrounds it. From the moment when we talk about interaction with the economy, we talk about the interaction between a natural non-agricultural vegetative space, and another shaped by man's action and hand. In this context we can consider the studies of several researchers like Marsh that emphasizes, in spite of this interaction, the consequences of the unfolding of the ecosystem and the social costs of the same manipulation made by man. In another scale Turner emphasizes the triumphalism of the domestication of the wild world by human action [13]. In this work I will use economical history just to evaluate the relational field that Portugal had with his exportation, and to establish the motives of its safeguard. I will then start to make the economical valorization of this good, and then try to establish based on that measures that where taken for its safe keep.

\subsection{Literature Revision Pau-Brazil as an Economic Asset in Portuguese Economy}

For this academic field it's necessary to intercourse the matters of Environmental History, with the bases of the economy of early modern world, perceiving its major characteristic. The most preeminent feature of Early Modern Economy was its dependence of natural conditions. Nevertheless, to aboard this issue, we can't be too much an Economist, neither an Environmentalist but something in between.

One of the conditions to establish intercourse between both academicals worlds, it's related with the approach. The economy cannot be restricted to the agriculture products, but also to activities and the resources of the forest. The same natural resources were of major importance in the Early Modern age. The forest, in general was a way to complement the recourses of subsistence as a great source of fuel.

Nevertheless all the studies until now worked the matter off Pau-Brazil in an economical basis. To understand this asset, it's necessary to establish its importance like an economical commodity. One of the mains points, as stated in the Environmental history, it's the action and interaction of man with the ecological resources. In an economic term, the product in debate, it's considered the first economic cycle in Brazil being the first good exported from Vera Cruz after it Brazil, too Europe by Portuguese contractors. Not only because of the quality of its timber, quite resistant, but also because of the red that could be extracted from here to paint in the clothes, which was much appreciated by Italian city states, who were manufactured, that explains its importance [14]. And its trade, in spite of not being the major trade good from Brazil, was still very important in the XIX century [15]. In the XVII century according with Brandão, it was still the second most exported product after the white gold the sugar export [16]. But, that it's not the only question rose related to the trade of this study object. According to Frederic Mauro, the Pau-Brazil trees had the following size: about 20 to 30 meters and very hard logs; once shopped them had 1, 5 meter and weight about $30 \mathrm{~kg}$ which.

In the ends of the XVI century, and in the beginning of the XVII century the main trade of Pau-Brazil was sent to the Netherlands. According to Frederic Mauro, it was exported in 1670 about 1000 toros of the same timber to the northern Europe, where the Dutch acted as resellers in the same region [17].But the root of northern Europe doesn't imply a full stop in the Mediterranean trade. In the same year, according to the quoted document, it was sent to Livorno Italy about 1000 toros, to be traded by indigo in India [17]. Prior to that, to the end of the XVI century, we have some data of a Dutch trading house that provides us the following numbers of 814932 pounds, in the years 1578 - 1579, sent to Arnemuiden. In the XVIII century, records of this trade are more rare because it starts to loose its importance in the Portuguese re-exportation. Historians, with exception of some notes of Frederic Mauro, don't study its trade. Even the master piece study in this tree - from Bernardino José de Sousa - has wide 
information to the period of 1803 - 1822, but does none mention to the chronological segment in debate. Due to its importance in Brazil Economic History I wonder, why such an absence of study?

\section{Results Pau-Brazil and Portuguese Trade in the End of XVIII Century}

Has it been showed this was an important asset that felt of importance in the XVII century, but in the XVIII century how was it?

According with Diogo Carvalho Cabral in the period in revise, the exportation of Pau-Brazil to Portugal reached the amounts of $£ 1.885$ pounds exported between 17961811 had been just half of the value exported in 1788 $£ 4.084$ [46]. Following these data, he problematizing if the wood production of Pernambuco would have felt into decline, our production was being passed aside the trade balances (by contraband). Let us here by consider the part of Pau-Brazil in Portuguese international economy and trade. After the war of succession of Spain, there is a decrease on the commerce of this product. In opposite the period among the years 1732-1739 was a period of sudden growth that leads it to reach a maximum of 31.33 Guilders per 100 pounds, until 1766 there is stability in its price in Brazil, from this date and until 1780 there is a low trend [18]. The Netherlands, in the pre and post restoration, absorbs a significant percentage of this wood and redistributes it; even, to the north of Europe [17]. The demand for this colorant plant follows the development of textile manufacturing, which is important in the early industrial revolution. However, even with the joint occupation of Portuguese and Dutch, the supply of this wood was enough to satisfy the international market of the XVII century [17].

This chronological period at the end of the eighteenth century brings together a strange historiography consensus, where it is unanimous to affirm the Portuguese economic vitality, as result of the measures of Marques de Pombal and the international conjecture; Brazil knows in the second half of the XVIII century a diversification of its production. This diversification had its positive consequences, contributing for the basis of the Portuguese wealth by re-export the goods of Brazil to the international market. Although there was a growth of products originating in Portugal, like the case of wine and salt, that didn't had the economical weight of the products of Brazil [19]. The Portuguese colonial economy at the end of the XVIII century had as its main destination the European markets, demonstrating a great vitality in the international context [20]. During this period, Brazil was an indisputable pillar of Portuguese prosperity, both as a supplier market for products and as a recipient market for manufactured goods. However, for the period under study, $64.4 \%$ of the products sent it aboard were from the re- export of colonial products, whose demand in the international markets had increased from the 70's to 90 [21]. This diversification, promoted by D. Rodrigo de Sousa Coutinho, was inspired by the division of labor of Adam Smith, creating an idea of regional production specialization, in view of the international market [22]. About the goods from Brazil six of them made about 95\% of the re-exports of the colonial products. And from those the most valued were white or brown sugar and cotton which together made about $70 \%$ of re-exports from Portugal to Europe [21]. This addictive, sugar, that was one of the most valued trade good, had a new boom becoming the most important asset in the re-export of Portugal. This diversification of production also means diversification of the trading partners, although England receives $40 \%$ of exports, Portugal has active trade relations with Italy and the United States along other nations/states [20].

As António Almodovar and José Luís Cardoso stated, there is a great importance given to agriculture in the economical thinking [23]. But could have been just agriculture, the use given to this Portuguese colony? Like José Jobson de Arruda affirms, the colony was a main source of income because of the use of the several natural goods. Those where not restricted to agriculture products, but all the goods that could be profitable in the terms of XVIII century economy. This notion of wealth enters in contact with the natural history, whose propose was to know all the productions of utility for men in his daily life. For the study of the final years of the XVIII century there is a great deal of sources in A.H.U and in Torre do Tombo that allowed us to study the same phenomena. Sources like: Ships products maps, Portuguese Trade Balance, Ships entrance in Portuguese harbors, gives a view of the commerce in the XVIII century which includes information about Pau-Brazil. I searched for several institutions, including Brazilian University's, and the silence in the historiography production of this subject it's astonishing. In spite of that early importance at the end of the XVII century, as José Jobson the Arruda demonstrates Pau-Brazil doesn't figures on the Portuguese list of most valuable exportation's to Europe. But, in spite of the lost of prominence, doesn't imply a full stop of exportation neither of importance. The study of some products, both by Portuguese and Brazilian researchers, has been conducted in the notion of economic cycles. The same notion, in spite of still being an operative concept, it starts to lose the methodological value. Like Frederic Mauro, appointing several examples, that the cycle theory it's a generalization. To strengthen is statement he regards that in the period where apparently the sugar cycle was dominant, there was not a reduction of volume of PauBrazil trade, but instead he observes an increasing on its exportation [24]. In this process of diversification, with the results in the Portuguese re-exportation economy, I launch the question and Pau-Brazil? 
In the end of the XVIII, as indicated by José Jobson de Arruda, it occupied the 15th position on the totality of exportation's don't demonstrating, apparently, a great impact in Portuguese economy [25]. In comparison with the re-exportation of sugar and cotton, the exports of PauBrazil only represented about $1 \%$. In the total of the exports of Pernambuco to Portugal it represents about 2\% of the re-exportation. Now, the Pau-Brazil was not as high-priced, as sugar, or as Cotton, or leather, at the colonial level (Graphic 1). On the other hand if we looked at quantity, we would be tempted to indicate leather as the main product of re-export from Brazil. The decisive factor to establish the weight of a product in the XVIII century trade was not the quantity but the price per arroba.

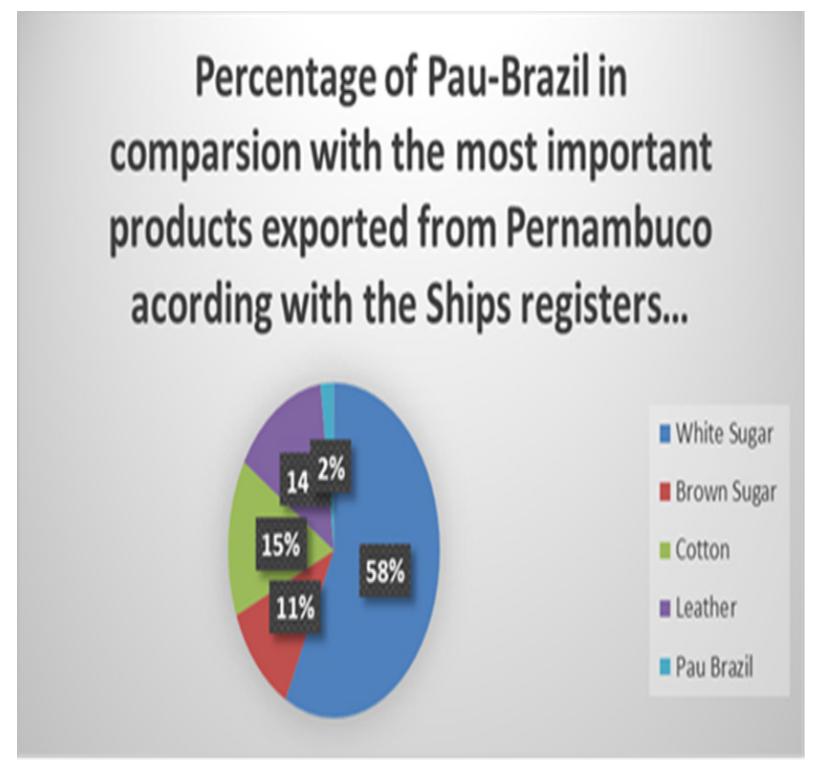

Sources: A.H.U, Conselho Ultramarino, avulsos, Brazil, Pernambuco, Caixa 177, Doc no 12423, 18 July 1791; A.H.U, Conselho Ultramarino, avulsos, Brazil, Pernambuco, Caixa 181, Doc n 12621, 23 July 1792; A.H.U, Conselho Ultramarino, avulsos, Brazil, Pernambuco, Caixa 181, Doc $\mathrm{n}^{\mathrm{o}}$ 12623, 12 September 1792; A.H.U, Conselho Ultramarino, avulsos, Brazil, Pernambuco, Caixa 185, Doc no 12880 , 17th May 1794; A.H.U, Conselho Ultramarino, avulsos, Brazil, Pernambuco, Caixa 197, Doc no 13522, 29 March 1797. INE: Balanças Comerciais do Reino de Portugal, 1796, 1797, 1799, 1800.

Graphic 1. Percentage of Pau-Brazil in comparison with the most important products exported from Pernambuco According with the ship registers between $1796-1800$.

Once it is a monopoly product, there is no information about Pau-Brazil price in the A.H.U documents. There for it is crucial to see the commercial scales of the Kingdom, where the price per quintal is present. In 1797 was calculated 1,801.5 quintais of Pau-Brazil to 1000 the quintal in a total of $1,801 \$ 500$ reis. In 1799 about 10,030 quintais of Pau-Brazil were sent to 1000 quintais for a total of 10,030 \$000. In 1800, about 12,149 quintais of Pau-Brazil were sent to 1,000 reis the quintal in a total of $\$ 12,149,000$ cruzados. This price meant that its value was not high, what places him in a peripheral economic position. Along with this comparison, we can note two specific moments in the export of Pau-Brazil to Portugal. Between 1790 and 1800, comparing the sources of the cargo maps with those of the House of India, they show a difference of 2688 quintais, with a total of 76,623 quintais being sent in these ten years from Pernambuco, with about 73,935 quintais being received in Lisbon. Among the trends the data provided allowed us to conclude that the pick of the exportation of this asset to Lisbon was between 1790 - 1795 were where sent to the Kingdom about $76 \%$ of this good in that decade. Nevertheless the information available in the records of the House of India indicates that $70 \%$ of the Pau-Brazil was sent in the same period (1790-1795). Despite the percentage difference of $6 \%$, compared with the data taken from the load maps, and even given the lack of data from the house of India to 1790, the large period of re-export of Pau-Brazil are the first five years of the decade. However despite this factor, there is an export of about 76623 quintais in the period of ten years to the kingdom according to the data of the cargo maps, and 73935 according to the records of the house of India, and came from Brazil approximately about 26920 toros. Among these data provided by both the Cargo Maps and the India House Records, there is a difference of 2688 quintais.

A first factor is that the India House registration for the year 1790 is not available, being that data missing. Even in the absence of such information there are discrepancies between the different data compared at annual level. In the years in which high values of quintais appear in the house of India, the sum of the load maps does not correspond, which indicates a lack of unanimity in the sources. From 1797 to 1800 there is a fantastic recovery from the collection of Brazil wood, which increases to 12149 quintais, making about $45 \%$ of the exports of this period. But in 1796 there is the most unusual case, since both the cargo maps register the scent of about 100 quintais, and the Indian house registers about 660 quintais received. There was a crash in the average of the order of $10 \%$, according to the data of the Load Maps, being the lowest value of the export of this product.

Until then it is not problematic, it becomes problematic when the data of Commercial Balance of the Kingdom presents that it was received from Pernambuco near 1801.5 quintais of timbers of the woods in study. This huge difference raises certain questions, such as what is the difference in the data presented? What destination would have been given these woods? The absence of sources does not allow me to reach any conclusion. However I have data to understand the impact of the PauBrazil break, according to the load maps, as well as the records of the house of India. And to question what impact it had on the economy of Pernambuco, from that period. Soon does not represent a significant weight in the colonial economy, in comparison with other products (Table 1, Graphic 2, Graphic 3). 
Table 1. Pau-Brazil sent from Pernambuco according different sources:

\begin{tabular}{|c|c|c|c|}
\hline Year & $\begin{array}{c}\text { Ship } \\
\text { registers }\end{array}$ & $\begin{array}{c}\text { House of India } \\
\text { (Casa da India) }\end{array}$ & $\begin{array}{c}\text { Balanças } \\
\text { Comercias }\end{array}$ \\
\hline 1790 & 3490 & 0 & 0 \\
\hline 1791 & 15875 & 13061 & 0 \\
\hline 1792 & 14189 & 16435 & 0 \\
\hline 1793 & 8000 & 8243 & 0 \\
\hline 1794 & 8872 & 6484 & 2939,5 \\
\hline 1795 & 7674 & 7548 & 1801,5 \\
\hline 1796 & 680 & 1008 & 0 \\
\hline 1797 & 100 & 660 & 10030 \\
\hline 1798 & 4938 & 3574 & 12149 \\
\hline 1799 & 2805 & 12724 & 26920 \\
\hline 1800 & 10000 & 4198 & \\
\hline Total & 76623 & 73935 & \\
\hline
\end{tabular}

Sources: ANTT/Torre do Tombo: Alfândegas de Lisboa, Casa da Índia, liv. 657, 1790-04-20a 1790-10-15.; ANTT/Torre do Tombo: Alfândegas de Lisboa, Casa da Índia, liv. 652,1791-03-21a 1791-0913.;ANTT/Torre do Tombo: Alfândegas de Lisboa, Casa da Índia, liv. 610, 1792-01 a 1792-11.; ANTT/Torre do Tombo: Alfândegas de Lisboa, Casa da Índia, liv. 603,1793-01-30a 1793-10; ANTT/Torre do Tombo: Alfândegas de Lisboa, Casa da Índia, liv. 1585,1795a 1796.; ANTT/Torre do Tombo: Alfândegas de Lisboa, Casa da Índia, liv. 661,1795-04-07a 1794-11-04.; ANTT/Torre do Tombo: Alfândegas de Lisboa, Casa da Índia, liv. 660,1795-12-29a 1795-11-27.;ANTT/Torre do Tombo: Alfândegas de Lisboa, Casa da Índia, liv. 1586,1796-12-16a 1797.; ANTT/Torre do Tombo: Alfândegas de Lisboa, Casa da Índia, liv. 1587,1798-08-07a 1798-12-01.; ANTT/Torre do Tombo: Alfândegas de Lisboa, Casa da Índia, liv. 1696,1799-01-02a 1799-12-11.; ANTT/Torre do Tombo: Alfândegas de Lisboa, Casa da Índia, liv. 1697, 1799-12-12a 1799-12-16.; ANTT/Torre do Tombo: Alfândegas de Lisboa, Casa da Índia, liv. 1699,1800a 1801. A.H.U, Conselho Ultramarino, avulsos, Brazil, Pernambuco, Caixa 177, Doc no 12423, 18 July 1791; A.H.U, Conselho Ultramarino, avulsos, Brazil, Pernambuco, Caixa 181, Doc n ${ }^{\circ}$ 12621, 23 July 1792; A.H.U, Conselho Ultramarino, avulsos, Brazil, Pernambuco, Caixa 181, Doc $\mathrm{n}^{\circ}$ 12623, 12 September 1792; A.H.U, Conselho Ultramarino, avulsos, Brazil, Pernambuco, Caixa 185, Doc n ${ }^{\circ}$ 12880, 17th May 1794; A.H.U, Conselho Ultramarino, avulsos, Brazil, Pernambuco, Caixa 197, Doc no 13522, 29 March 1797. INE: Balanças Comerciais do Reino de Portugal, 1796, 1797, 1799, 1800.

\section{Tendencies of Pau Brazil Sent from Pernambuco from the diferent sources}

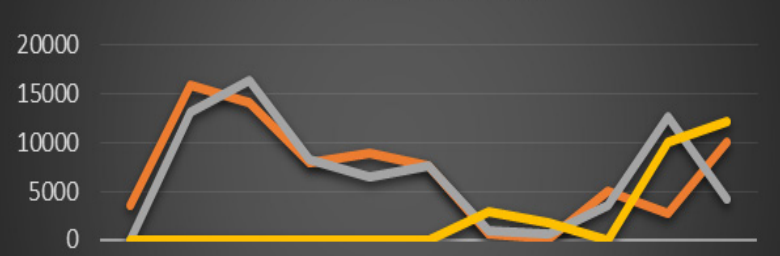

17901791179217931794179517961797179817991800

Ship registers

House of India (Casa da India)

Balanças comercias

Sources: ANTT/Torre do Tombo: Alfândegas de Lisboa, Casa da Índia, liv. 657,1790-04-20a 1790-10-15.; ANTT/Torre do Tombo: Alfândegas de Lisboa, Casa da India, liv. 652, 1791-03-21a 1791-0913.;ANTT/Torre do Tombo: Alfândegas de Lisboa, Casa da Índia, liv. 610,1792-01a 1792-11.; ANTT/Torre do Tombo: Alfândegas de Lisboa,
Casa da Índia, liv. 603,1793-01-30a 1793-10.; ANTT/Torre do Tombo: Alfândegas de Lisboa, Casa da Índia, liv. 1585,1795a 1796 ; ANTT/Torre do Tombo: Alfândegas de Lisboa, Casa da Índia, liv. 661 1795-04-07a 1794-11-04.; ANTT/Torre do Tombo: Alfândegas de Lisboa, Casa da Índia, liv. 660,1795-12-29a 1795-11-27.;ANTT/Torre do Tombo: Alfândegas de Lisboa, Casa da Índia, liv. 1586,1796-12-16a 1797.; ANTT/Torre do Tombo: Alfândegas de Lisboa, Casa da Índia, liv. 1587,1798-08-07a 1798-12-01.; ANTT/Torre do Tombo: Alfândegas de Lisboa, Casa da Índia, liv. 1696,1799-01-02a 1799-12-11.; ANTT/Torre do Tombo: Alfândegas de Lisboa, Casa da Índia, liv, 1697,1799-12-12a 1799-12-16.; ANTT/Torre do Tombo: Alfândegas de Lisboa, Casa da Índia, liv. 1699,1800a 1801. A.H.U, Conselho Ultramarino, avulsos, Brazil, Pernambuco, Caixa 177, Doc no 12423, 18 July 1791; A.H.U, Conselho Ultramarino, avulsos, Brazil, Pernambuco, Caixa 181, Doc $\mathrm{n}^{\circ}$ 12621, 23 July 1792; A.H.U, Conselho Ultramarino, avulsos, Brazil, Pernambuco, Caixa 181, Doc n ${ }^{\circ}$ 12623, 12 September 1792; A.H.U, Conselho Ultramarino, avulsos, Brazil, Pernambuco, Caixa 185, Doc $\mathrm{n}^{\circ}$ 12880, 17th May 1794; A.H.U, Conselho Ultramarino, avulsos, Brazil, Pernambuco, Caixa 197, Doc n ${ }^{\circ} 13522,29$ March 1797. INE: Balanças Comerciais do Reino de Portugal, 1796, 1797, 1799, 1800.INE: Balanças Comerciais do Reino de Portugal, 1796, 1797, 1799, 1800.

Graphic 2. Tendencies of Pau-Brazil sent to Lisbon according the Different Sources

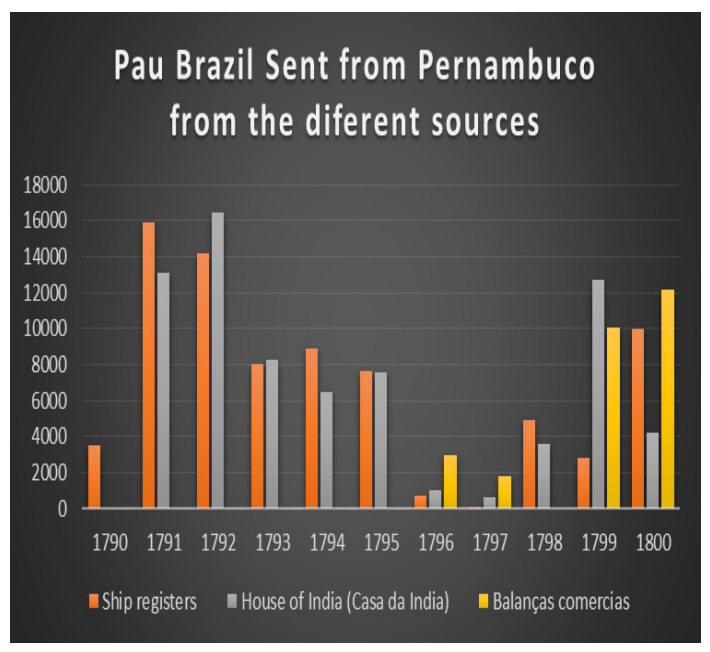

Sources: ANTT/Torre do Tombo:Alfândegas de Lisboa, Casa da Índia liv. 657,1790-04-20a 1790-10-15; ANTT/Torre do Tombo: Alfândegas de Lisboa, Casa da Índia, liv. 652,1791-03-21a 1791-09 13.;ANTT/Torre do Tombo: Alfândegas de Lisboa, Casa da Índia, liv. 610,1792-01a 1792-11.; ANTT/Torre do Tombo: Alfândegas de Lisboa, Casa da Índia, liv. 603,1793-01-30a 1793-10.; ANTT/Torre do Tombo: Alfândegas de Lisboa, Casa da Índia, liv. 1585,1795a 1796.; ANTT/Torre do Tombo: Alfândegas de Lisboa, Casa da Índia, liv. 661,1795-04-07a 1794-11-04.; ANTT/Torre do Tombo: Alfândegas de Lisboa, Casa da Índia, liv. 660,1795-12-29a 1795-11-27.;ANTT/Torre do Tombo: Alfândegas de Lisboa, Casa da Índia, liv. 1586,1796-12-16a 1797.; ANTT/Torre do Tombo: Alfândegas de Lisboa, Casa da Índia, liv. 1587,1798-08-07a 1798-12-01.; ANTT/Torre do Tombo: Alfândegas de Lisboa, Casa da Índia, liv. 1696,1799-01-02a 1799-12-11.; ANTT/Torre do Tombo: Alfândegas de Lisboa, Casa da Índia, liv. 1697,1799-12-12a 1799-12-16.; ANTT/Torre do Tombo: Alfândegas de Lisboa, Casa da Índia, liv. 1699,1800a 1801. A.H.U, Conselho Ultramarino, avulsos, Brazil, Pernambuco, Caixa 177, Doc n⿳ 12423 , 18 July 1791; A.H.U, Conselho Ultramarino, avulsos, Brazil, Pernambuco, Caixa 181, Doc no 12621, 23 July 1792; A.H.U, Conselho Ultramarino, avulsos, Brazil, Pernambuco, Caixa 181, Doc $\mathrm{n}^{\mathrm{0}}$ 12623, 12 September 1792; A.H.U, Conselho Ultramarino, avulsos, Brazil, Pernambuco, Caixa 185, Doc n ${ }^{\circ}$ 12880, 17th May 1794; A.H.U, Conselho Ultramarino, avulsos, Brazil, Pernambuco, Caixa 197, Doc no 13522, 29 March 1797. INE: Balanças Comerciais do Reino de Portugal, 1796, 1797, 1799, 1800.

Graphic 3. Pau Brazil sent to Lisbon According the different sources

It continues, in this period, to have a relative demand in the great textile centers like in London, were it was one of the export markets of Pau-Brazil. Nevertheless at the end of the eighteenth century, this wood had others main markets, like Hamburg, where about 60\% (17412 quintais) 
the same tree were sold between 1796 and 1800 . The reexport of this product is almost a barometer of what happens in re-exports of other products. This city is of the first position in 1796, 1797, 1800, in the consumption of the products of Brazil Pau-Brazil in particularly. This was followed by Britain which is secondary nation of re-export of this product with a total of $15 \%$ (4185 quintais), even reaching preeminence in 1798 and 1799 . Followed by the third, Italy, with a total of 9\% (2639), over these years, except in 1800, which is in second place. The forth is Castile, where it was re-exported about 6\% (1705) of the total. The Netherlands who were fifth, with a total of $5 \%$ (1488 toros), corresponding to the first two years of the data collected. (Table 2A, Table 2B, Table 3, Graphic 4 and Graphic 5). And last Prussia, were it went about 3\% of the total [24]. This is accompanied by a drop that accompanies all the other nations that consume this product, Denmark which has increased by 1799 to 1500 quintais of this product (Table 3, Graphic 5).

Comparing that the years of the fall of this product were in 1796-1797, there is no correlation with the shortage at the base of the break of this product. Except for the substitution of Italy by the Netherlands, it follows all the parameters and trend of the nations that commercialize Portuguese colonial products. In fluctuations, despite the fall in Hamburg demand, they are slight in the demand for this product. In spite of that low value, its consumption in Hamburg make it very important.

Table 2A. Pau-Brazil re-exported to Europe in Quintais:

\begin{tabular}{|c|c|c|c|c|c|c|}
\hline Year & Hamburg & Great Britain & Netherlands & Italy & Castile & Barbary \\
\hline 1796 & 2655 & 0 & 144 & 768 & 217 & 55 \\
\hline 1797 & 7643 & 768 & 1344 & 702 & 510 & 108 \\
\hline 1799 & 5664 & 1353 & 0 & 512 & 596 & 178 \\
\hline 1800 & 1450 & 2064 & 0 & 657 & 382 & 87 \\
\hline Total & 17412 & 4185 & 1488 & 2639 & 1705 & 428 \\
\hline
\end{tabular}

Sources: INE: Balanças Comerciais do Reino de Portugal, 1796, 1797, 1799, 1800.

Table 2B. Pau Brazil re-exported to Europe in Quintais:

\begin{tabular}{|c|c|c|c|c|c|c|}
\hline Denmark & Sweden & Russia & Germany & Malta & Prussia & Total \\
\hline 0 & 9 & 1 & 44 & 15 & 0 & 3980 \\
\hline 0 & 0 & 0 & 0 & 0 & 0 & 11075 \\
\hline 0 & 0 & 0 & 0 & 0 & 480 & 8783 \\
\hline 400 & 0 & 0 & 0 & 0 & 400 & 5440 \\
\hline 400 & 9 & 1 & 44 & 15 & 880 & 29206 \\
\hline
\end{tabular}

Sources: INE: Balanças Comerciais do Reino de Portugal, 1796, 1797, 1799, 1800.

Table 3. Percentage of Pau-Brazil sent from Lisbon for the deferent's parts of Europe from 1796 - 1800.

\begin{tabular}{|c|c|}
\hline Hamburg & $60 \%$ \\
\hline Great Britain & $15 \%$ \\
\hline Italy & $9 \%$ \\
\hline Castile & $6 \%$ \\
\hline Netherlands & $5 \%$ \\
\hline Prussia & $3 \%$ \\
\hline Barbary & $1 \%$ \\
\hline Denmark & $1 \%$ \\
\hline
\end{tabular}

Sources: INE: Balanças Comerciais do Reino de Portugal, 1796, 1797, 1799, 1800. 


\section{Pau-Brazil Reexportad form Lisbon to Europe acording to the Balança Comercial Between 1796 $-1800$}

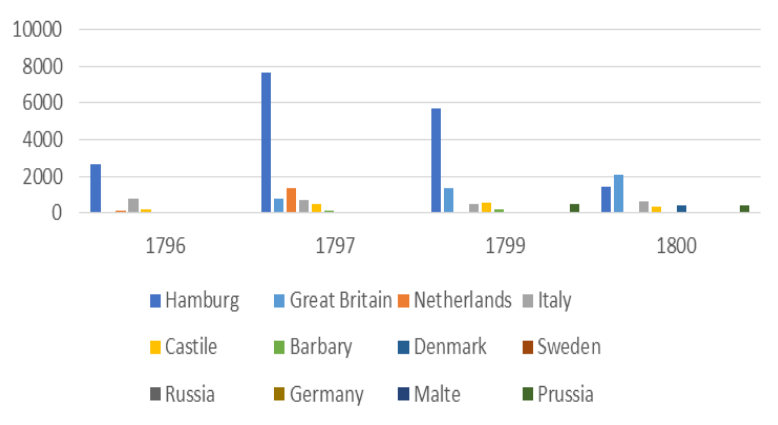

Sources: INE: Balanças Comerciais do Reino de Portugal, 1796, 1797, 1799,1800 .

Graphic 4. Pau-Brazil Re-exported form Lisbon to Europe according to the BalançaComercial Between $1796-1800$.

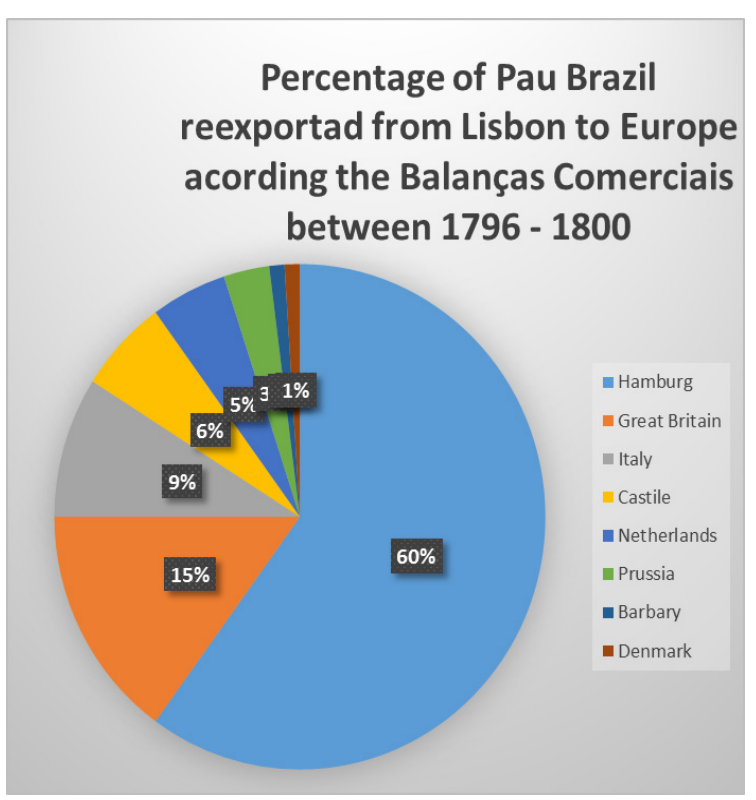

Sources: Sources: INE: Balanças Comerciais do Reino de Portugal, 1796, 1797, 1799, 1800 .

Graphic 5. Percentage of Pau-Brazil Re-exported from Lisbon to Europe according the BalançasComerciais Between 1796 - 1800.

In spite of those percentages this product was very valorized in the international markets (according to Jorge Pedreira and Jobson de Arruda) reaching 778, 7\% of profit taxes [24], [25]. This phenomenon, more that the quantity it's consequence of over price by unit that allows to balance the reduction of unities [24]. The Pau-Brazil that came to the price of $1 \$ 000$ reis the quintal, and was sold to $4 \$ 400$ reis allowed some return of $3 \$ 400$ reis profit per quintal. Nevertheless, there is a steady decline in demand for this product in Hamburg from an average of 8000 toros to about 2,000toros in 1800 .

To understand this valorization we must also understand, the exotically goods in the end of the XVIII century. The eighteenth century is characterized by the search for exotic goods among which the different parts of the Overseas [26]. About this search Maxine Berg and Elizabeth Eger report the demand for Asian products, mainly Chinese silks and porcelains [27]. The expansion of this consumption, which leads to the appearance of new products in daily consumption, shows that there was a market for any new productions.

This is explained by the diversification of the supply and demand, which illustrates why didn't experience a total break. When there is a breakdown of one of the main markets for this product, a fragmentation of its demand by some trading partners, permitted the stabilization of this product. Now here is a question, what is the weight, besides sugar, that Brazil wood had in the Portuguese colonial products? Despite being $1 \%$, it is the fifth most re-exported product in Brazil to kingdoms capital. And we speak of $1 \%$ which means earnings, over the whole of the 4 years, in the order of $24,032,188 \$ 400$ reis, so we speak of a relatively high value in that period of time. This percentage margin, although minimal, corresponds to the highest value, after the 6 most important products in commercial traffic.

The reduction and rarity, among a consumer society in growth would ensure a market for those same goods. In the case o Pau-Brazil we have a product that could be use either to ship building, either to taint the tissues made in the factory's with a red ink. Not being consumers good for a person, it was a asset with a great profit tax, in a moment where industrial revolution was making its steps. There is a change here, compared to the XVII century, of the main exporters of this wood. The Netherlands had access to an Asian variant, which explains the reduction of exports. Great Britain had access to the colored cotton that came from Asia, not having to export Pau-Brazil in great qualities. From these nations there is a loss of interest in Pau-Brazil, since they do not need their action as a dye plant. Contrasting these data with those of scarcity, I can affirm that the problem generated ends up not having an influence on the re-export of this matter. The trade balance, compared to 1796 , is relatively low approaching 2000 quintais. Since 1782 because of its trade with America [28], Hamburg its one emergent commercial city establishing a trade bridge between America and the German city states. Part of that importance, as well, came from the connection between Hamburg, and the Atlantic ports. Nevertheless the importance of Pau-Brazil insured a trade with a harbor that meant access to goods provided from Germany. This, in potential, meant the continuity of a relationship that allowed Portugal to have a positive economic balance. In this case the re-exportation of $\mathrm{Pau}$ Brazil, in spite of its low numbers, allowed Portugal to keep Superavit in the relation with Hamburg. In the case of Italy it can be integrated in the crisis, after the famines of 1763 - 1765 when Italy start import raw materials and agriculture goods instead of luxury goods [29]. Pau-Brazil due to its coloring properties ability's was a raw material 
who could be used in the painting of clothing in the Italian markets. On the other hand, this re-exportation from Brazil helped Portugal to reestablish connection with old markets and to open new markets for trade.

And even in re-exports, with the data we have access did not have a significant impact, since in the year 1796, remittances to the kingdom were over 2000 quintais. And that the decrease is continuous, and the losses of demand even with the recovery don't have an impact in the economy. In my view, we are facing a decline in the demand for Pau-Brazil in the international context.

\subsubsection{Results: The Decrease of Pau-Brazil}

\subsubsection{Causes and Measures of Preservation}

Seen the importance of this wood, let us start to attend the motives for deforestation, and scarce of the Pau-Brazil in the period of study. If this data about the tree, can be tackled in an economical approach, can also be studied in an ecological turn. Inquiring the Portuguese empire, in the subject of environmental history, has been more approached on the acclimation of Asian plants in America, or about the migration of native African consumption plants to America (case of mandioca). That question makes us consider about the impact of trans-Atlantic economy in the exploration of colonial resources? Paul Ward, as already was stated, the early modern expansion as a "pathway of ideas, and species" crossing around the globe [10]. In the perspective of an interconnected history or a global history, allows understanding the ramification of the circulation of goods and ideas around the Earth. But, and about the impact of the same process, in the point of depart of the species?

According to Marsh, as already written, there the action of men, in the natural has deep consequences. If by one hand it could have its effects on economy, for the other implies that this good was being reduced to a near extinction. In one hand, the history of nature, can connect with the history of circulation of plants, can always connect with their extinction. If in an international economy perspective the interpretation was, that the PauBrazil was being difficult to supply, in an ecological perspective meant that this timber could be disappearing at an extinction level. This affected its economic use, because it could not be the risk of its extinction was never be commercialized again. It's not necessary to analyze the numbers, to not make the information superfluous so let's see what literary information (the sources) can provides about the question. Connecting this numbers with environmental demand, the functions to establish the trends to regular services can be applied to environmental goods [47]. The functions, as only difference it's the accounting of the pay, that it's related to natural elements and not to natural goods [47]. Has already saw, this product was valued and had a price in European Markets. In answer to the second question placed by Diogo de Carvalho Cabral, about the shortage of Pau-Brazil, lets inquiry what information the sources of the A.H.U can provide to trace the causes of the deforestation.

In 1792 came the first warnings about the exhaustion of this wood from the part of Pernambuco, mentioning that could bring an irreparable damage to both Pau-Brazil and Naval construction timber. This question it was also pointed, as the motive for the lower exportation of the mentioned assets [30]. Presented this situation the crown choose to use a preventive approach, but without stop the shipping and cutting of the trees. The recommendations followed was to choose well the toros of the wood that would be sent to the Ribeira das Naus, so that the contractors do not continue to refuse them. In this line of action, at the date of this office, it was not possible to see such a gauge, referring to the thinner logs that is already paid for by the Fazenda Real, for while do not reach the required dimension is suspended the purchase of more Pau-Brazil [31].

But in 1796, after having been ordered an inquiry into the state of the woods, the first real solid information appeared [32]. That Oficio gives a picture of a devastated forest witch (according to the source), results in a reduction in is size.

In July of that same year, there was another officio, in which he made known the state of the Alagoas wood. The Judge Corregidor José da Mendonça Mattos Moreira, made a personal inspection of those bushes. The situation becomes serious to the point of the contractors João Roque Jorge, to send a letter to the king, stating that he has only received half of what he should have receive from this wood [34]. The governor is justified by the scarcity of the tree, which he had already warned the crown. Although the Governor has increased the value of this product, in order to attract more labor to its extraction, the values according to him, are not enough to fulfill the contract [8]. Leaving here the question, what are the causes of this drastic reduction in the wood of Pau-Brazil?

According to Anthony Pena, one of the ecological fields of interpretation it's the part of men: in forestry, fire, environmental change [10]. It's inseparable the part of men in the reductions of the Pau-Brazil forests, what forces to regard the multiple motives in its core. There are four causes pointed out in the documents to justify this devastation: The chopping of the wood, the breach of royal contract, Smuggling, the use of the timber in sugar production.

About the chopping of the wood the Governor of Pernambuco indicates, that for 50 years there were, in these forests, cuttings that surrounded the average of 10 12 quintais year demonstrating great admiration for the contraction found. It is made by this governor a diagnosis, in which he points out that since the cancellation given to the junta of the city had been annulled, and given the authorization to the peoples to make the cuts as before, it caused a shortage of the same wood [30]. All those who wanted to make the cut were called, and to say the price 
they wanted. What is not possible to reach a legal consensus, it was established that it would be a thousand kings by quintal [33]. About this question, according to Cippola, the peasants of modern Europe had poor incomes [2], which made it justifiable by the high investment in subsistence goods [2]. In Europe, incomes were low, which forced smallholders to seek additional resources from those they had. In this logic, the small owners had to seek either income or extra resources to be able to subsist or be a complement for sale. At this point it becomes essential to speak of the concept of agricultural economy as Daniel Thorner has developed: as a system in which production aims at self-sustenance and that surpluses seek to look for what the household does not produce. However, within the criticism made by Francesco Boldizzoni, we must distance ourselves from the theoretical bases that are not economy and an economic object, but rather subsistence seeking complementary in the market. As the historian himself indicates many of the choices, rather than those made on a rational basis, are made on the basis of more irrational than a rational parameters [5]. As part of that critic, he points that cliometric interpretations begin with a theory that it's then applied to history, instead of the theory being elaborated based on the data and crossing with cultural, economic and social question of the historical period.

Other of the causes mentioned is the breach of the royal monopoly, causing that the action of the people in the cutting of these forests had reduced drastically those woods. Did this occur in 1791, if it is possible, as it was? From 1791 to 1795 with the reduction of those forests to, that level? It is certain that there is an increase of 3000 quintais to the order of 15000 from 1790 to 1791 , which in fact with the increase of demand, reduced the number of trees available, beginning the abrupt decline from 1793, affecting the region from which these woods are extracted, to an almost irremediable point.

But those were not the only causes that were indicated. Other causes for this thinning, according to this document, were the fires, to give pace to the sugar plantation a practice that was being recurrent since the introduction of that plant in Brazil [32]. Many of the best land were already used for the mills, which forces more areas of forest to be felled in order to obtain new soil for cane planting. A later office of the same governor indicates that in the lack of fertilizers, fire was being used to burn the soil as an alternative fertilizer [35]. Along with the search for new soils, it was also used to fertilize those lands that already were used for sugar cultivation. This theory, it's interesting but to what point can explain the destruction of the forest. If we talk about lands near the river, then we are certainly talking about one of the main causes to pave the path for sugar plantation. Sugar and its cultivation need a lot of water, and sugar cultivation in Pernambuco, was in a period of high, being the 3rd main supplier to the kingdom [24]. If we speak of the use of this method to conquer lands for this purpose, in riverside zones, then it will do justice to this intention. In the environmental level, this meant the destruction of the landscape, not to use the same wood, but because of the sugar trade. One of the theories, and research basis in Ecological History, it's the part of men as a changing force in the Natural Landscape. As already stated, this parts (according to Turner) the domestication of nature by humanity. In the ends of the XVIII century, sugar trade was gaining - after the rebellion in Tahiti - a new boom in Brazilians exports. This meant that the woods would have been shopped, to give place to new land of cultivation. It's a hypothesis since like it happened in Bahia, most of the farmer's start - due to its high profits - to turn to sugar production instead of subsistence good productions [36]. This question however was not restricted to subsistence goods, but also to the woods. In spite - in the case of Bahia there is separation between the lands where were the sugar mills (reconcavo), and the woods in the end of XVIII century who, where in danger. The main cause, more than the shipbuilding, was due to the maniac cultivation. To protect the woods, all forests around the coast and in river banks, where considered royal property and could not be given in sesmarias [37]. According to that theory, that action had fundament cause the landscape was being tamed, due to men's interests. But, was the fire the main cause for the forestation of Pau-Brazil? There is here a pattern that should be considered, like it's clear in the documents - in comparison with what happened in Bahia - one of the main actions taken by farmers was to burn land and shop wood to have more available soil for the production of sugar. But, can this be applicable in this case? The scenario indicated riverside as well as coastal lands with a marked deforestation [32]. Sugar culture it's mainly strong in regions where there is a great deal of water flew, which doesn't happened when we go to the inland. And fire would consume large areas, and not only a specific species. Therefore, to be used to justify the cuts in the interior would not make sense, for this reason since the sugar, by the conditions of production, more to the backwoods there is no longer.

Another reason mentioned is the use of wood as fuel wood for sugar mills, which alone do not justify the level of deforestation found [35]. Whether given the geographical question or connected to the sugar production in Pernambuco in the second half of the XVIII century. Only the fires themselves were not enough to cause this damage. Another cause is the cutting of illegal wood, on this when doing the above-mentioned survey the forests, it is noted that excessive cuts were made, losing much of the forest heritage.

On the other hand they were done in an irresponsible and negligent way, seriously damaging the trees. The reason for negligent action in the eyes of the Portuguese authorities is the prohibition of calafates (caulk) and carpinteiros (carpenters) in Brazil, given the smuggling of 
timber in Rio de Janeiro that all caulkers and carpenters are sent back to the kingdom [38]. Paradoxically what would be to avoid the cutting of illegal wood, ended up having an opposite effect in Pernambuco? This measure deprived of a large part of good labor to carry out the thinning of the forests where there was wood. That makes the people do it, on their own initiative. Already in the XVI century the king, who had allowed this activity to his subjects, found himself obliged to place this business on a royal contract, given the excessive slaughter of these trees [17]. With the lack of labor there is no one who makes these cuts in condition, nor does anyone who goes to the forest cut the wood. Who made the cuts was not able to do it, damaging seriously the forests of Pernambuco. On the other hand, if there is no good price, the manufacturers stop cutting them or if they do, then they did it clandestinely do what the extent of the coast is not possible to watch. This issue is therefore related to the lack of skilled labor, which leads to unqualified people doing it. There is the difference in the type of cut that is made, since those who are not professional, make the cut of subsistence, which is for the wood, for the construction, but not with commercial intentions. The thinning that was badly done resulted in an inability of the forest to regenerate, with consequent reduction of its trees. One of the reasons pointed out by various offices is the lack of maintenance of the areas, for lack of an intendant that was to watch the forests and to supervise whether or not there were illegal cuts. As a consequence both of the fires and of the bad cuts, the woods near the coast have been extinguished making, the wood not already near the coast, but rather the 12 leagues from the port of Embarque [32].

The smuggling it's another of the causes pointed, as responsible to this decrease. According to the documentation in the summer it was easy to access this captaincy, namely by the Bahia da Traição, where any ship could come, being close to the woods where the cut is made [39]. There were thus conditions for the smuggling to be made, but was this a real cause? The smuggling has resemblance with the myth in Fernando Pessoa, is the all or nothing of the Portuguese documentation. It is often mentioned, but there is rarely any concrete data to allow its investigation. Even if you want to make projections, there is no data that will allow you studied properly. In the first place, it is difficult to quantify, there is a lack of studies to compare in the different parts of Europe, what has arrived from products of Brazil, through this practice, comparing with the different statistical sources for this period. Contraband is in the view of José Jobson de Arruda, one of the main reasons for the retraction of the Brazilian colonial economy [24]. Jorge Pedreira contests the premise of Jobson de Arruda, stating that for this in what he designates as an estimative, they presuppose a balance in the commercial operations that are not there [25]. Even the negative level of trade is too small to be the work of commercial competition. One of the factors responsible for its increase, and demand is the price increase of a particular product, which makes it attractive and cheaper to obtain. This phenomenon cannot be seen here, since re-export to the kingdom did not value this product, which would correspond to a maximum of $2 \%$ of that captain's exportation to Lisbon. At the price level, as we have seen, from the colony to the metropolis were 1 $\$ 000$ reis a yard, with a valuation of $4 \$ 4400$, on the other hand as we have seen this business did not have a strong impact on the economy, neither Brazilian nor Pernambuco. In order to get a sense of the size of the contraband, we would have to know where the ships came from, their origin, and destination, which is not even mentioned in the documents. It was not difficult to know which ships and which nations did the activities, in the case of Benguela, Angola, there is reference to the presence of ships to smuggle in the coast. And even in Brazil there are several that indicate where the ships come from, if the destination is unknown. In the case of Pernambuco, the idea of smuggling is associated, but it is not even a debauchery, much less one tries to know what nation it was, which in itself makes the idea suspicious [39]. On the other hand the documents affirm a possibility, indicating a place from where it could be done, but does not attest that there is indeed such a practice. Soon there are means by which one can know, or determine whether it was or not smuggling.

In a general view, we can't determinate only one cause for the scarce of Pau-Brazil. In my view all of these factors, with exception of smuggling, made their contributions to the deforestation and it's in short supply. If by one way the search of complementary profits, forced the farmers to chop the tree, the culture of sugar - in spite of not being the most appropriated soil - was one of the causes to make the chop. All those reasons, by itself, could not be cause for the deforestation. But all of them together had its influence in the disappearing of this wood. In an ecology interpretation, the causes may consider men changing influence in the landscape (sugar cane); And economical ones (source of income, that led to sesmarias and fires). Given these problems, the following question arises, what solutions have been found?

\subsubsection{Solutions to Stop De Deforestation}

Talking of measures of preservation of Brazilian wood, it's not only regarding the period in study. By the beginning of the XVII century, in 1605, that the Portuguese crown tried to restrict the cut of the same wood to ho had concessions promulgated by the provedor-mor. Nevertheless in spite of the situation, the authorities took measures to stop and regulate the chopping of the trees. In what concerns both this period, we have the work of Warren Dean about the Brazilian rainforest. Not making a large comment to this interesting book, let's go directly to the results this historian presents about the period in question. This author concludes that 
Portugal was losing its economy to other European Nations and was necessary a larger fleet, more diverse production and economy from the colonies, better colonial infrastructure, and, perhaps, major productive integration inside the colonies itself in the sectors that sustain economy. In this question he underlines the risk of deforestation that was very high, and using science for that effort could (in case of a situation of continuous exploration) accelerate its demise; in the other hand a situation of cautions and delivered exploration could allowed it's preservation and renewal being economically beneficial. According to Warren Dean some hypotheses of preservation of the Amazonia Rainforest where made in the beginning of the second half of the XVIII century. Measures that, by one hand pass by the use of science, where there wasn't a stop in the cut of trees but a selection that could not take more than a certain type and number. Most of the criticism, it's based more of the little know of the species, then actually some practical measures and the creation of a botanical garden in Rio de Janeiro. Nevertheless the theme, he makes no reference of this case of the Pau-Brazil, doing for the XVIII century a small survey about the contacts with the ideas with Europe [40]. In the other hand, he studies more the creation of botanical gardens in that chapter like a way of conservation.

The pattern established was the regulation of the cutting, to avoid the extinction without compromising the economy. About the economy process of forestation of Brazil there as been a field some research, like the works of Dean Warren, in which they resume a topic of the destruction of the Brazilian Atlantic Forest by the Portuguese.

Nevertheless beside that general view, the governor suggests other solutions. The governor warns the crown that in order to have large forests of Pau-Brazil and other woods, it was necessary that these forests be saved for a period of $10-12$ years in order to regenerate themselves [41]. Within this line of action it was recommended preservation measures, as well as of conservation. This measure implicates the total stop of chopping, what meant that for that period it would not be done no chopping at this wood to allow that it could be regenerated. On the fields of economics, we should consider the base of perindustrial economies. Early Modern and previous economic times, where widely depend of Nature. The climate, plagues, scarce, could be the basis of great crises. And, also, was largely dependent either for energy terms, either for resources to complete the scarce resources of a person. And in the economic boom that Portugal was having, it wasn't wise to suggest any measure that could harm but one that could mean the best of both worlds. The solutions for this problem are debated between what we can call the notions of preservation and prevention. But, how can we apply this concepts historically without commit any anachronism. The concept of Preservation collects several practices that, for the conservation of wild life, and natural world, imply the restriction of the access of men at certain species animal and vegetable. To achieve those principals, it's tried to maintain natural areas as closest possible of their natural condition. Conservation, by other hands, has it implicate the possibility of some, but reduced interaction with men but at a level that the environment wouldn't be damaged. Other concept, that we should take an account; it's the notions of prevention. In which the natural areas must be intact, and protected from the action of men.

The first to prevent further reduction of the mata, is through the vigilance preceded by Sergeant mor António da Costa Araújo, reinforcing penalties and threats if they were made [32]. This is a preventive measure, in order to avoid further reduction by preventing people from undergo the illegal chopping. In the same line of action to avoid the cuts and the action of the individuals in the matta, it is on behalf of the governor forbidden the cut in the best forests, incurring in serious penalties that would be caught in these actions [32]. Another part of the solution found goes through a Bureaucratic solution, in order to better control the state of the forests. To do this, and to maintain the forests, the office of a superintendent of forests is created; that would be in charge of the preservation of these forests [43]. When the post is created, it suggests that it be given to a skilled, intelligent man of these matters, who will reserve for the crown the best woods. Within this profile it is suggested that should be awarded to José de Mendonça Matos Moreira, so that he could investigate these forests in a competent way [39]. After that survey was carried out, the reserve of the best forests for the Crown, the remaining was for the use of the Peoples [32]. This measure is based on the same practice done to the pine forests of Leiria, where there is a superintendent of forests responsible for their investigation. The demarcation by tombo begins, being the superintendent responsible to all the cuts are necessary to the wood[32]. Within the same bureaucratic part, a monopoly action was developed on the riverside lands. The creation of this office of Juiz Conservador das Mattas, according with B.N.L Souza, would be responsible to regulate the shop the woods; improve the methods of chopping; and see if the timber already chopped where of great quality; but also conserve the woods, and know what diseases may affect it [44].This solution, can be regarded as preventive measure, that - if by one hand - permits the chopping in which can be also regarded as with conservation proposes, because I theory would allow some chopping but, without disturbing the trees, it can also be inter operated as of preventive objectives. The creation of those offices had as a main objective to insure that those forests would be unharmed and that the chopping wouldn't affect them to extinction near level. In case of any law breakers be found, they were instructed to punish them according with the Portuguese Law. 
Another solution was the search for new forests, in order to ensure that there is continuity in the shipment of Pau-Brazil. In the absence of timber of the tree in study, the crown starts to search the same commodities in other capitanias. In this period, within its plans of autonomy from the jurisdiction of the captaincy of Pernambuco, the captaincy of Paraiba sends several offices in which allude to the quality of its woods advocating that its separation from Pernambuco would be more propitious to this contract than its dependence on Pernambuco [42].

In 1796 there is an inspection of the neighboring forests, to see which ones have the best woods and those that do not correspond to the desired measures. An examination of the forests and ports of Paraiba confirms this same facility for the shipment of construction woods, nearby ports and forests, and easier paths [31]. However, the nonexistence in Paraiba of forests that correspond to the criteria of the Kingdom.

What leads to search in the forests of Pernambuco in the region of Alagoas [32]. In this way the solution found, in the absence of good forests in Paraiba, is to intensify the demand within the own capitania of Pernambuco. Hence, after an extensive and cautious investigation, the forests of Inhaum, Fiquia, and Benguela found the site of the cuts calculated to be roughly 10,000 to 12,000 quintais, with these lands being able to send timber [33]. Finding out in these woods, where there were the logs of greater quantity and quality, not only of Pau-Brazil but also for the naval construction [32]. But if they helped to reduce the shortage of timber to the crown was unable to solve the situation in the Pernambuco forests. The commander of the same comarca, Alagoas, José de Mendonça Matos Moreira states that in the woods where no cut had been made, woods of palm groves,according to the meirinho, had woods inside the conforms [39].

Another measure introduced, with the same finality, was the creation of cotas and the given to the Jesuits the Monopoly of the cut of Pau-Brazil [23].This measure is part of a request of 1797 to conserve the forests, prohibiting their cuts to individuals, restricting them to actual use [32]. The same prohibitions were extended to the forests of Paraiba, besides those of Pernambuco [32]. These forests are all considered exclusive property of the crown, and no one can make use of them, neither for chopping neither for sesmarias [45]. This measure, can be include in conservative measures, as it separates part of the forest from the general populations permitting a reduction of the actions caused in them.

One of the causes that the documents indicate, as a cause for this deforestation, letters of sesmarias given, which led the Portuguese crown banning this practice in areas that are planted or near the rivers as well banned future award of land for that zone. To survey this process the corregedores, reviewed the possession of the lands. To whom the sesmaria already had been given, in the lands near the coast, as well as the land near the woods, must bring the documentation to be ascertained its legitimacy. On the other hand, it is ordered to demarcate the lands were the forests are, and where there are the rivers to take into account the richest forests, so that they can be used only by the crown [45]. In this perspective a situation of legal action is used, in consonance with the exploration of the territory to solve the situation. This measure aimed at legally restricting the ownership of land, as well as of people who could harm them. It is hoped, in my view, that this would prevent the peoples from making use of the restricted forests the royal authority. The governor testifies that the corregidores were always open-minded, hoping to punish whoever incurs in that crime. In order to cope with this measure, it is tried to generalize the use of the already ground cane, as fuel instead of using the wood for the sugar boilers [43]. It is thus tried to give alternatives to the peoples, so that they do not use the wood in the boilers, trying to implant this method already used in the Antilles. This measure, can be regarded as a conservation measure, in spite no being conceptualized with this notion in the same historic period. By restricting access to the forests, the chopping of the wood and the right of property, was only off the Portuguese crown and its authorities that could provide access as well of the chopping that should be done by crown regulation. In theory that would allow, by the restriction both to lands, and forest that the trees wouldn't be harmed, and therefore

In another perspective we have here a sample of the care generated by the diversification of production, in view of colonial exports. Treating-When dealing with a product that only exists in Pernambuco; its disappearing could result in serious damage to the economy, while sugar is in several captaincies. Diversity of production was safeguarded, guaranteeing the continuity of a product. Once the matter was settled legally, the quality of the Pau-Brazil of Alagoas was examined, and two logs were sent to José de Mendonça de Mattos, Judge and Corregidor of the same county, where the quality is documented [35]. The decision is nothing new, unless the monopoly on forests is strengthened. In this way the traditional system of exploitation is maintained, being protected of legal action, being revoked the freedom of cut of the same forest, to benefit of the crown. The same measure reinforces the initial practice made by the Portuguese crown on the Brazilian forests. In my view, despite the different reasons, the lack of this same wood, paralleling the brutal increase in exports from 1790 to 1791 , is the deregulation that leads to indiscriminate cutting, the other issues being responsible to its near extinction.

\section{Conclusions}

The concept of nature, was more important, not only in official language, but also in safeguarding the natural 
goods of witch the economy depended in XVIII century. The same good, if economically loses its importance continually from de XVI century to XVIII century, his profits and importance among other products makes it important to preserve. Dough most of the historiography tends to study this matter in an economical perspective, it's possible in the ends of the XVIII century to study it, due to the level of information and documentation available in the different Portuguese archives, in an ecological perspective. In economical view the same diversification of production that accompanies a favorable recovery of sugar does not accompany Pau-Brazil, which has a peripheral position in Brazilian products. This product had an insignificant weight both in the economy of Pernambuco and in the Portuguese re-exports economy. However the scarcity of this and other woods, leads to a reversal of a policy of free exploitation of it, in the face of a monopoly policy. But, nevertheless, what it's not achieved in quantity it's achieved in profit for overvalued, reaching the perceptual value of $778,71 \%$ in the European Markets. In spite of the absence of great volumes of trade, it's generated a greater cost that the search turns in extra profits. That makes one product, in spite of the low weight in exportation the high profit range made it important. This economical importance would be the basis to try to safeguard the same accent, not by preserving it as we understand today, but under the logic of the Ancient regime economy from which meant a balance between preservation and collection. Beside the economical numbers, the official documentation provides us safeguard to see, within that periods view, the causes that explain the numbers in question. As which it is seriously reviewed several aspects of economic policy in Pernambuco, reducing the sesmarias. The drop in exports to Portugal is not accompanied in the same dimension at the international level. There is a general fall of the same product, with few increases of its demand in Europe. However, despite the weak demand, there is a stabilization provoked by the diversification of commercial partners that although they look for it in small quantities, they allow a reduced fluctuation of the demand of the same ones. However, although it also accounts for only one per cent of the weight of the economy in the trade balance, Hamburg has no significant value. The weak impact, and also seeks, of this wood internationally, related to the transformation of the dye industry, also explains this drop in demand. However, given the already weak demand, and despite the statistical paradoxes in this case, the fall of the Pau-Brazil does not have a significant impact on the reexport, neither in the global scope, nor in the regional scope. However, this is due to a fall in demand, a steady reduction in demand and a stabilization of demand. Soon after the Pau-Brazil scarce, it does not have a significant impact on its demand. But, due to the fact that it's involved, in an economical search of the exotique the profits could go very high making it an interesting product to spare. There for, in a moment that Portuguese economy was getting a boast, it meant that the slightest gain could make a difference. If by one hand, the numbers indicate the commercial importance of the wood, it also indicates the level of deforestation that the same woods

In this economical process it's necessary the safeguard of its woods, so it could continue to produce timber for reexportation. With that guideline it's necessary to act to preserve the same accent so it doesn't extinguish. In that part, the number can be interpreted in an ecological view, connected with the causes of the scarce of timbers. For that reason there its several causes that could explain its scarce all connected with human and economic activity like: give pace to sugar production; illegal and unregulated cuts and contraband. It's not possible to determinate just one cause, all of them with the exception of smuggling to which there was no evidence, only suspicion, may had contribute to the deforestation. The solution however, didn't pass by totally prohibition of the cutting of the woods, as it his subjacent in the thought of D. Tomás José de Mello, but regulation in the cuts and search so it wouldn't lose its economic value. About the safeguard of the same wood, once Portuguese authorities had a long relation with this product, was not to send it to any botanical garden. The preservation here must be seen in symbioses with economy and within the standards of the XVIII century. Under that duality that Portuguese crown use, due to the economical conjecture, prevention according to principles of ancient regime, and Portuguese tradition. It passed by creating means of regulation, about the cut, about to the access to the tree, and also means of control and coercion of necessary. Part of that measure's involved the creation of alternatives for the cut of the wood, determination from where and if she could be cut. To prevent the chopping, the applications of new methods and techniques to boil sugar, that tried to avoid or reduced the use of the timber. By regulation creating measures to stop the same cuts, was integrated the creation of the rank off the conservador das mattas, that should be responsible about the prevention of the Atlantic tropical rainforest and was a preventive action, watching it and to stop in the field any law breaker providing as well some information to crown about the states of the woods. On the other hand it was reviewed also the sesmarias, to stop that they would be given land where the Pau-Brazil was. By reorganizing this Portuguese practice it would permit that the people had restricted access to the land, which implies that they could not have the possibility to reach the woods, and cut the trees, and was a conservation measure and avoid more damage that it had been done. But, the Portuguese crown issued orders to try to minimize damage that would try - by making those woods less accessible to avoid further deforestation. And also, to create alternatives to the use of timbers, in the boiling of sugar, so that trees were spared. These measures intended to prevent the disappearing of the Pau-Brazil keeping some 
control over those woods. Those measures, to avoid the same problem that occurred in Pernambuco, were extended to the forest of Paraiba. Here we can see that the Portuguese crown used these measures as model, to the safeguard of a specific species of tree. The ecological measures taken by the Portuguese crown, where preventive to avoid that the Pau-Brazil woods suffered a bigger shortage. To sum it up, the need of the good, in the context of Portuguese economy, as an asset of exotic value, force the crown to create measures to protect the same good so it could maintain its weight in economy of the XVIII century.

\section{REFERENCES}

[1] Richard H. Groove, Ecology, Climate, and Empire colonialism and global environmental history, Cambridge, White Horse Paper, 1997.

[2] Carlos M. Cipolla, História Económica da Europa PréIndustrial, Lisbon, edições 70, 1988.

[3] E. Kula, History of Environmental Economic Thought, London/Nova York, Rutledge, 2001.

[4] Erik Gómez-Baggethun, Rudolf de Groot, Pedro L. Lomas Carlos Montes. Introduction. The history of ecosystem services in economic theory and practice: From early notions to markets and payment schemes in Ecological Economics xxx (2009).

[5] Francesco Boldizzoni, The Poverty of Clio: resurrecting economic History, Princeton and Oxford, Princeton University Press, 2011.

[6] Ulrich IM Hof, A Europa no Século das Luzes, Lisbon, Editorial Presença, 1995.

[7] http://insights.som.yale.edu/insights/what-is-ecologicaleconomics.

[8] Pascal Duris, "Histoire Naturelle" in Dictionaire européen des Lumieres, direc. Michael Delon, Paris, Presse Universitaire de France, 1997.

[9] Donald Worster, the Nature of Ecology, Sierra Clube, São Francisco, 1977.

[10] Anthony N. Penna, the Human footprint A Global Enviormental History, 2nd edition, Blackweel, 2015.

[11] Warde, Paul \& Sorlin, Sverker (2007). "The Problem of the Problem of Environmental History: A Re-reading of the Field and its Purpose". Environmental History. 12 (January 2017), p. 107 - 130.

[12] Charles D. Kolstad, Environmental Economics, Nova Yorque/Oxford, Oxford University Press, 2000.

[13] Andrew C. Isenberg," Historicizing Natural Environments: The deep roots of Environmental History", in A Companion to Western Historical Thought, pp. 372 - 375.

[14] Jorge Couto, A Construção do Brasil, Lisbon, Edições Cosmo, 1995.
[15] Ronaldo Vainfas, pau-brasil in Ronaldo Vainfas direc. Dicionário do Brasil Colonial, Rio de Janeiro, Objectiva, 2000.

[16] Harold B. Johnson, "Pau-brasil", in Maria Beatriz Nizza da Silva, Dicionário da História Colonial Portuguesa no Brasil, Lisbon, Verbo, 1994.

[17] Fréderic Mauro, Portugal, o Brasil, e o Atlântico 1570 1670, Vol I, Lisbon, Editorial Estampa, 1997.

[18] Virgílio Noya Pinto, O Ouro Brasileiro e o Comércio Anglo Português: Uma Contribuição aos estudos da Economia Atlantica Século XVIII 2a Edição, São Paulo, Companhia Editora Nacional, 1979.

[19] Leonor Freire Costa, Pedro Lains e Susana Munch Miranda, História económica de Portugal, Lisbon, Esfera do Livro, 2011.

[20] Stuart B. Schwartz, "A economia do Império Português", in A Expansão Portuguesa, 1400 - 1800 direc. Francisco Bethencourt e Diogo Ramada. Lisbon, Edições 70, 2010.

[21] Valentim Alexandre, Os sentidos do Império, Porto, Edições Afrontamento, 1993.

[22] António Almodovar and José Luís Cardoso, A History of Portuguese Economic Thought, London and New York, Rutledge, 1998.

[23] Bartolomé Bennassar \& Richard Marin, História do Brasil, Lisbon, Teorema, 2000.

[24] José Jobson de Arruda Andrade, O Brasil no Comércio Colonial, São Paulo, Atica, 1981.

[25] Jorge Pedreira, Estrutura Industrial e Mercado Colonial Portugal e Brasil (1780 - 1830), Lisbon, Difel, 1994.

[26] Paul Butel, Histoire de L'Atlantique de L'Antiquité à nos jours, Paris, Perrin, 1997.

[27] James Foreman Peck, "Long Distance Trade: Long Distance trade between 1750 - 1914", in The Oxford Encyclopedia of Economic History, editor Joel Mokyr, New York, Oxford University Press, 2003.

[28] https://www.hafen-hamburg.de/en/history

[29] https://www.britannica.com/place/Italy/Reform-andEnlightenment-in-the-18th-century

[30] D. Tomás José de Melo, Office of the Governor of Pernambuco, D. Tomás José de Melo... informing the quantity and quality of the wood... caused by the lack of deposit of them, May 25, 1792, AHU, Conselho Ultramarino, Brazil, Pernambuco, Roll 215, Doc no 12582.

[31] D. Tomás José de Melo, Office of the governor of Pernambuco D. Tomás José de Melo to the Secretary of State of the Navy, Martinho de Melo e Castro on the qualities of wood staves and Pau-Brazil, April 4, 1791, Brazil, Pernambuco, Conselho Ultramarino, Roll 211, Doc $\mathrm{n}^{\circ} 12340$.

[32] D. Tomás José de Melo, Office of the Governor of Pernambuco D. Tomás José de Melo to the Secretary of State for Foreign Affairs and War and Interim of the Navy Luís Pinto de Sousa Coutinho, on the destruction of the forests, February 26, 1796, AHU, Conselho Ultramarino, 
Brazil, Pernambuco, Roll 227, Doc nº 13225.

[33] D. Tomás José de Melo, Ofico Second Way of the Governor of the Captaincy of Pernambuco, D. Tomás José de Melo, ... On the examination of quality made to the bulls of Pau-Brasil of the region of Alagoas, July 22, 1796, AHU, Conselho Ultramarino, Avulsos, Pernambuco, Roll 229, Doc no 13326.

[34] D. Tomás José de Melo .... On the reasons that had the Real Estate of that captaincy to not fulfill the payments due to the contractors of Pau-Brazil João Roque Jorge and Filhos, March 29, 1797, AHU, Conselho Ultramarino, Avulsos, Brazil, Pernambuco, roll 232, doc 13503.

[35] D. Tomás José de Melo, Office (1st Way) by D. Tomás José de Melo Pernambuco (Secretary of State of the Navy and Overseas) D. Rodrigo de Sousa Coutinho on the recommendation to use oxen and plow to cultivate the lands, sending a brief description of the methods of cultivating land manipulation of the genera that are exported from that captaincy, May 14, 1798, AHU, Conselho Ultramarino, Brazil, Pernambuco, Doc no 13809.

[36] Keneth Maxwell \& Maria Beatriz Nizza da Silva, "A Politica" in Nova História da Expansão Portuguesa: O Império Luso-Brasileiro 1750 - 1821. V. 8, Lisbon Editorial Estampa, 1996.

[37] F.W.O. Mortan, "The Royal Timber in Early Colonial Bahia", in the Hispanic American Historical Review, Vol 58, No 1, (Feb., 1979), p. 47.

[38] Mr. José Luís de Castro, Office of the Vice King of Brazil Mr. José Luís de Castro to the Secretary of State for the Navy and Overseas D. Rodrigo de Sousa Coutinho ... sending a list of carpenters and caulks in the port, not commenting on the His Excellency, José Luís de Castro, Secretary of State of the Navy and Secretary of State of the Navy. Ultramar D. Rodrigo de Sousa Coutinho... on the lack of caulkers and carpenters to work on the vessels of Rio de Janeiro and the consequent delay in leaving the next train, September 27, 1799, AHU, Conselho Ultramarino, Brazil, Rio de Janeiro, Doc. No. 12890.

[39] D. Tomás José de Melo, Letter from the Governor of the Captaincy of Pernambuco to D. Maria I informing about the state of ruin ... and the need to create a superintendent of the forests for that place November 5, 1796, AHU, Conselho Ultramarino, Brazil, Pernambuco, Rolo, 230, Doc n ${ }^{\circ} 13421$.

[40] Warren Dean, A ferro e fogo a história e a devastação da mata brasileira, $1^{\text {a }}$ reimpressão, São Paulo, Companhia das letras, 1995, p. 135.

[41] D. Tomás José de Melo, Ofico Second Way of the Governor of the Captaincy of Pernambuco, D. Tomás José de Melo, ... On the examination of quality made to the bulls of Pau-Brasil of the region of Alagoas, July 22, 1796, AHU, Conselho Ultramarino, Avulsos, Pernambuco, Roll 229, Doc nº 13326.

[42] Fernando Delgado de Castilho, Office of the Governor of Paraiba, Fernando Delgado Freire de Castilho, to the Secretary of State for the Navy and Overseas D. Rodrigo de Sousa Coutinho On the Memory he makes about Paraiba.... And from the losses suffered by agriculture and commerce, the farm the authority of the governor and the military with the subjection of Paraiba to Pernambuco, (post) 1798, A.H.U, Conselho Ultramarino, Brazil, Pernambuco, Doc no 2471.

[43] D. Tomás José de Melo, Letter (3rd Way) to the Secretary of State for the Navy and the Overseas D. Rodrigo de Sousa Coutinho Regarding the care he has had, March 29, 1797, AHU, Conselho Ultramarino, Avulsos, Brazil, Pernambuco, Roll 232, doc 13519.

[44] B.N.L Sousa, Pau-Brazil, São Paulo, Campanha Editora Nacional, 1939.

[45] D. Tomás José de Melo, Letter (3rd Way) from the Governor of the Captaincy of Pernambuco ... on the order received to control the courts in the forests of the captaincy, July 12, 1797, AHU, Conselho Ultramarino, Brazil, Pernambuco, doc $\mathrm{n}^{\mathrm{o}} 13573$.

[46] Diogo de Carvalho "O Bosque de Madeiras" e outras Histórias: A mata Atlântica no Brasil colonial (séculos XVIII e XIX), Tese apresentada como parte dos requisitos para a obtenção de título de Doutro em Ciências, Universidade Federal do Rio de Janeiro Instituto de Geociências Departamento de Geografia Programa de pós graduação em Geografia, Rio de Janeiro, Janeiro de 2010.

[47] Charles D. Kolstad, Environmental Economics, New York/Oxford, Oxford University Press, 2000. 